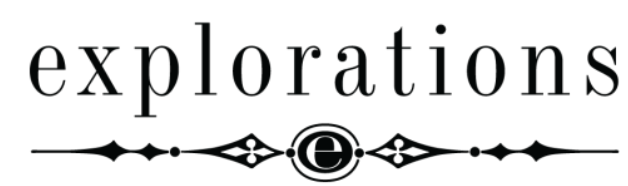

Explorations: A Journal of Language and Literature

\title{
Florentine Nights, or domesticating Romola: The forgotten Polish translation of George Eliot's novel
}

DOI: $10.25167 /$ EXP13.19.7.3

Ilona Dobosiewicz (University of Opole)

ORCID: 0000-0001-7259-2891

\begin{abstract}
The paper discusses an anonymous Polish translation of George Eliot's 1863 novel Romola, published in the late nineteen-twenties by the Edward Wende publishing house. The Polish version, which appeared with the title Noce florenckie (Florentine Nights) and a photo of Lilian Gish on the cover, may be seen as an early case of a movie tie-in. The discussion focuses on the domesticating strategies used by the Polish translator, who paid attention only to the elements that move the personal story of Romola, Tito and Tessa forward, and removed most of the elements that deal with the history and culture of Renaissance Florence. As a result, the translation becomes a highly simplified paraphrase that reads easily and fluently, but gives the reader almost no insight into the multidimensional world of George Eliot's novel, the complexity of which arises in part from Eliot's foreignizing approach towards the Italian sources used for Romola.
\end{abstract}

Key words: George Eliot, Romola, Polish translation, movie tie-in.

For anyone interested in British literature and culture 2019 is a significant year, for it marks the bicentenary of the birth of such figures as Queen Victoria, John Ruskin, and George Eliot. Despite her prominent position in the canon of English literature, George Eliot's popularity in Poland is rather limited, and few of her works have been translated into Polish. The two-volume selection of her works which contains Adam Bede and Scenes from Clerical Life was published in 1891-1892 and remains out of print. George Eliot's two best-known novels: The Mill on the Floss and Middlemarch have been translated by Anna Przedpełska-Trzeciakowska and published in 1960 and 2004 respectively. ${ }^{1}$ Interestingly, the only other novel to be translated into Polish is Romola, probably her least popular book, which poses many challenges for the translator because

\footnotetext{
${ }^{1}$ For a detailed discussion of these Polish translations, see Dobosiewicz (2016).
}

Explorations: A Journal of Language and Literature, 7 (2019), pp. 17-26 
of its complex language and almost encyclopedic accumulation of historical detail. The following paper will discuss this anonymous translation of Romola, described in the National Library of Poland catalogue as published no earlier than 1925 and no later than 1928, focusing on the domesticating strategies used by the translator, and arguing that the publication, which appeared with the subtitle Noce florenckie (Florentine Nights), is an early case of a movie tie-in.

Romola, first published in fourteen monthly installments in the Cornhill Magazine from July 1862 to August 1863, constitutes a striking departure from George Eliot's earlier and later novels, for she abandoned her familiar setting of nineteenth-century rural England, choosing instead late-fifteenth century Florence. The novel abounds in historical details concerning life in the Italian city at the time of tensions between the ruling Medici and a Florentine party called the Arrabiati, who side with the Duke of Milan and the Pope, and the populist Piagnoni party influenced by the charismatic Dominican monk Girolamo Savonarola who oppose them. Savonarola rebelled against the humanist spirit of the age, burned books on a "bonfire of the vanities," and delivered fervent sermons about ridding the Church and the city of Florence of scourge and corruption. Interwoven with the public events is the personal story of Romola de' Bardi, the daughter of the classical scholar Bardo, and of Tito Melema, a young Greek-Italian scholar, who marries Romola and seduces Tessa, a young and naive girl who bears him a child. As Romola and Tito's marriage disintegrates, Romola falls under the influence of Savonarola and becomes deeply committed to his version of Christianity.

The idea for the novel came to George Eliot during a holiday in Florence in May, 1861 where she spent days in the Magliabecchian Library researching the life and times of Savonarola. On her return to England, she undertook an extensive and prolonged program of reading on the social and political history of fifteenth-century Florence in order to make the novel as authentic as possible. The preparatory notebooks indicate the scope of her research: "on buildings and battles, customs and costumes, fairs and funerals, state officials and religious orders; on topics as diverse as usury, the wool trade, horse racing, and the manufacture of spectacles; on politicians, philosophers, clerics, scholars, artists and poets" (Brown 1994, viii). Since Tito Melema has a Greek origin, George Eliot used the vast libraries of the British Museum to research Greece in the late fifteenth century. William Blackwood, her friend and publisher, observed that she was so meticulous with regard to realism that it hindered the novel's progress: "Her great difficulty seems to be that she, as she describes it, hears her characters talking, and there is a weight upon her mind as if Savonarola and friends ought to be speaking Italian instead of English" (Haight 1978, 349).

George Eliot's saturation in historical sources and her obsession with historical veracity may have been responsible for the fact that Romola is the least read of George Eliot's novels. Despite critical acclaim, it had little public success, for many readers felt so overwhelmed by the accumulation of historical detail that they found it difficult to focus on the personal dramas of her characters. George Eliot's vast research became a drawback for the novel. As Henry James put it, "Romola is on the whole the finest thing she wrote, but its defects are almost on the scale of its beauties. The great defect is that, except in the person of Tito Melema, it does not seem positively to live. It is overladen with learning, it smells of the lamp, it tastes just perceptibly of pedantry" (James 1971, 500). In a June 28, 1862 letter, Anthony Trollope worried that the sheer weight of historical and cultural references "would fire too much over the heads of ... [her] 
readers" and advised her to write to tens of thousands, and not to single thousands" (Booth 1951, 115).

Recently, George Eliot's work on Romola has been compared to that of a translator. The novel is set in Renaissance Florence, yet it contains discourse on nineteenth-century England. According to Lesa Scholl, "Eliot ... takes on a kind of travel writer/translator role, mediating between her English middle class and her invented late-fifteenth century Italy, in order to address nineteenth-century social issues - namely the position of women" (Scholl 2016, 166). Nicola Trott maintains that "since Romola's sources are for the most part in languages other than English, it is also a work of translation. Sometimes, ... it reads like a work in translation" (Trott 2003, 137). In the course of her research for the novel, George Eliot familiarized herself not only with fifteenth-century Italian but also with the variety of the Tuscan dialect spoken in Florence. As she noted in her journals, working on Romola, she was re-reading Machiavelli's Mandragola "for the sake of Florentine expressions" (Harris and Johnston 2000, 108). For George Eliot, subtle historical and geographical differences were important elements that shaped the beauty and power of language. In her efforts to capture the "real language" of the people of Florence and convey it to her English readers, she uses characteristically Tuscan expressions and literally translates them into English. For example, in Chapter One, a character named Bratti, described as "a grey haired, broad-shouldered man, of the type which, in Tuscan phrase, is moulded with the fist and polished with the pickaxe" (Eliot 1994, 11), says to Tito Melema: "you were not born of a Sunday - the salt shops were open when you came into the world" (Eliot 1994, 14). This is an Italian equivalent of the English idiom "you were not born yesterday," indicating a shrewd person, and, according to Andrew Brown's Explanatory Notes to Romola, Eliot has taken it from Boccaccio's Decameron. The novel abounds in such examples. To quote just a few: bolla di sapone (soap bubble) is an Italian phrase denoting something insubstantial, and in Romola, light talk is characterized as "a mere blowing of soap bubbles" (Eliot 1994, 324). In Chapter One, Bratti boasts of his intelligence, using the expression "I want no man to help me tell peas from paternosters" (Eliot 1994, 23). According to Brown, George Eliot found the Italian expression "s'io non conosco il bacilli da' paternostri" (Lit. "If I don't know peas from paternosters") in Franco Sacchetti's Trecentonovelle. The comparison is between a pea and a single rosary bead (Brown 1994, 558). In Chapter Four, the reader finds the phrase: "You come as opportunely as cheese on macaroni" (Eliot 1994, 39), which, as Brown explains, comes from the Italian expression essere come il cacio sui maccheroni, meaning to turn up at the right time (Brown 1994, 565). George Eliot also uses some Italian phrases that she chooses not to render in English in the main text, although she supplied a number of footnotes to the novel where she explained their meaning. For example, she uses thItalian phrase "Qui nacque il divino poeta" in the main text (Eliot 1994, 11), and translates it into English in the footnote: "The Divine Poet was born here" (Eliot 1994, 554).

When one chooses to look at Romola as a kind of George Eliot's exercise in translation's exercise in translation, one might argue that she adopts a foreignizing translational strategy, to use the terminology coined by Lawrence Venuti. Venuti distinguishes between foreignizing and domesticating literary translations. These two concepts of translation have a long history: whereas Horace in his Ars Poetica claimed that the poet who engages in translation should avoid word-for-word translation of the original text in order to create distinctive poetry, in an 1813 lecture entitled "On the 
Different Methods of Translating", Friedrich Schleiermacher., a German philosopher and theologian, advocated word-for-word literal translation in elevated language to create the effect of foreignness: "the more closely the translation follows the turns taken by the original, the more foreign it will seem to the reader" (Lefevere 1977, 155). Schleiermacher claimed that "Either the translator leaves the author in peace, as much as possible, and moves the reader towards him; or he leaves the reader in peace, as much as possible, and moves the author towards him" (Lefevere 1977, 74). According to Schleiermacher, the translator who uses a foreignizing approach or moves the reader towards the author maintains many original characteristics of the source text, such as cultural references that may not be obvious to the reader of the translated text, stylistic features uncommon in the target culture, and some elements of the target language. Drawing on Schleiermacher's thought, Venuti points out that foreignization involves "deviating enough from native norms to stage an alien reading experience" (Venuti 1995, 15-16). By doing so, the translator brings the reader closer to both the linguistic and cultural universe of the source text. At the same time, foreignizing translation resists fluency and underscores the fact that the text produced in the target language and culture is a translation. Venuti claims that by recreating the foreignness of the original text in the target language, a foreignizing translation draws attention to its ontological status as a translation and thus negates the erasure of cultural difference characteristic of any translating process. George Eliot's use of Florentine expressions, her close attention to historical and geographical differences, the sheer number of cultural references and their scope and depth produce the otherness of the world she created in her novel. As a result of her foreignizing strategies, the reader of Romola is moved towards the cultural and political milieu of Renaissance Florence and not allowed to forget that it is a world different from the one he or she inhabits.

To understand the strategies used by the Polish translator of Romola, it is important to take into consideration the cultural context which influenced the publication. The Polish translation of Romola appeared under the title Romola. Noce florenckie [Florentine Nights]. As has already been mentioned, the date of publication is not given; the National Library of Poland catalogue describes the book as translated from the English language and gives the timespan as no earlier than 1925 and no later than 1928. It may be assumed that the translation appeared in 1927, because the subtitle Noce florenckie, added most probably by the publisher, was an attempt on his part to tie the book to the 1924 film based on George Eliot's novel. It was the first feature-length silent film of any of George Eliot's works, some of which had previously been made into short films of approximately ten-minutes duration. The American movie adaptation of Romola, directed by Henry King and starring Lillian Gish as Romola, Dorothy Gish as Tessa and William Powell as Tito Melema had a running time of one hour and forty five minutes; it was shown in Poland in the early months of 1927 under the title Noce florenckie [Florentine Nights] and enjoyed considerable success with the Polish audience. It was advertised in many newspapers and journals. For example, the daily Lódzkie Echo Wieczorne of January 8, 1927 prints an advertisement for Noce florenckie calling it "najwspanialsze arcydzieło filmowe" [lit. the most wonderful cinematic masterpiece]. Large font is used for the title of the film whereas the phrase: "monumentalny dramat osnuty na tle powieści George Elista (sic) Romola" [lit. a monumental drama based on George Elist's (sic) novel Romola] is given in small print (8). According to the film reviewer for the illustrated art and literature weekly Rewja of March 20, 1927, "Noce florenckie z boską Lilian Gisch 
(sic) i jej siostrą Dorotą, spotkał się . . . z rekordowym wprost powodzeniem, to naprawdę warto ten wspaniały film zobaczyć. Wystarczy wspomnieć, że wytwórnia 'Loew-Metro-Goldwyn' nazwała Noce florenckie - jednym z najlepszych swych filmów”. [Lit. "the film Florentine Nights with the divine Lillian Gisch (sic) and her sister Dorothy achieved a record-breaking popularity.... This magnificent film is really worth seeing. It is enough to mention that the producers 'Loew-Metro-Goldwyn' called Noce florenckie one of its best movies" (Anon. 1927, 19). It is not surprising that the publisher of the Polish translation Romola might have wanted to capitalize on the film's success. The Polish version of Romola may be seen as an early example of the so-called tie-in novel a newly published edition of the novel which gets renamed to match the title of the film based on it.

To strengthen the tie between the book and the film, the cover bears the photograph of Lillian Gish as Romola together with the phrase Noce florenckie. In Applied Translation Studies, Tong King Lee notes: "[A] book/movie title or an advertising slogan is not an innocuous, standalone specimen of language; it carries on its shoulders the full burden of a creative idea or marketing campaign" (Lee 2018, 150). The title Noce florenckie is a constitutive part of the marketing campaign by the publisher of the Polish translation, for it reinforces the connection between the successful film and the novel. The actual title of George Eliot's novel - the word Romola - does not appear on the cover, but on the title page together with the subtitle Noce florenckie and the name of the author. The name of the translator is not given. The book is one of the installments of the Film Library - a short-lived series issued by the Edward Wende publishing house - which also includes the 1924 edition of Pierre Loti's An Iceland Fisherman (tied to Jacques de Baroncelli's 1924 film based on the novel) and the 1926 edition of Gaston Leroux's The Phantom of the Opera (tied to Rupert Julian's 1925 movie adaptation). Since adaptations of novels constituted a significant proportion of films produced in the nineteen-twenties, book publishers took to marketing their novels by tying them to popular movies.

The anonymous translator of the Polish version of Romola took great liberties with the original text of the novel, focusing only on the elements that move the personal story of Romola, Tito and Tessa forward, and removing most of the elements that deal with the history and culture of Renaissance Florence. The novel's historicity, its concern with clashing philosophies and social constraints, are reduced to a bare minimum, and the reader's attention is drawn to the private and the individual. As pointed out by Tong King Lee, "in most cases an act of translating is motivated and directed centrifugally, by which we mean it is undertaken for someone other than the translator, usually to satisfy some external utility" (Lee 2018, 150). This seems to be the case of the Polish translation of Romola which had to comply with the marketing strategy of the publisher. As a result, the Polish translation is closer to the film adaptation of Romola than to the novel by George Eliot. ${ }^{2}$ The film pared the multidimensional novel, rich in historical detail and intricately interwoven subplots, down to a basic melodrama. Noce florenckie also reads like a melodramatic tale. The momentous public events, the conflict between Renaissance humanism and medieval Christianity, the political power struggles - all the factors that placed the end-of-fifteenth century Florence at a crossroads in the intellectual history of Europe, described by George Eliot in often painstaking detail, are absent from the Polish

${ }^{2}$ The film is available at https://www.youtube.com/watch?v=3W7nUs968W4. 
version. Long sections of the novel are removed: the Proem and Epilogue, fragments of individual chapters, and entire chapters (XVI, XIX, XXXV, LI, LIV, LVII, LX, LXI, LXV, LXVIII). The translation becomes a highly simplified paraphrase that reads easily and fluently, but gives the reader almost no insight into the complex and multidimensional world of George Eliot's novel.

The excision of the Proem is particularly meaningful. In this fictionalized introduction to Romola, the narrator presents to the readers multiple points of view that interrogate the possibility of a stable and unified narrative perspective. George Eliot offers two competing visions of the past in the Proem: the first is presented from the perspective of the Angel of the Dawn who focuses on physical topography and universal human nature; the second view is that of a "resuscitated Spirit" of a fifteenth-century Florentine man who observes the changes in the city in the present day. Both are forbidden by the narrator to enter the city to examine "how it has all turned out" (Eliot 1994, 9), for it is the reader who is required to engage in the intellectual labor of making sense of the past. The Polish translator does not want to make any excessive intellectual demands on the readers; thus he removes all the textual elements that might disrupt the fluency of reading. Fluency, as Venuti reminds us, "assumes a theory of language as communication that, in practice, manifests itself as a stress on immediate intelligibility and an avoidance of polysemy, or indeed any pay of the signifier that erodes the coherence of the signified" (Venuti 1995, 60-61). Discarding the Proem where George Eliot questions the very idea of meaning as essential, timeless and universal; the translator clearly privileges immediate intelligibility and avoids polysemy. Venuti also notes that fluent domestication of foreign texts has an economic value: "enforced by editors, publishers and reviewers, fluency results in translations that are eminently readable and therefore consumable on the book market, assisting in their commodification" (Venuti 1995, 16). The Polish edition of Romola which ties the novel to the popular film is a commercial project; therefore the translator has to produce a text which will be easy to read and thus will appeal to a wide audience.

To attract readers and make the text accessible to them, the translator adopts a simplifying and ultimately reductive approach derived from domesticating strategies: he attempts to bring the text as closely as possible to the world of the reader, who is not required to leave his own linguistic and cultural universe, and is not overwhelmed by an abundance of historical detail because many - especially those that are more obscure or learned - references do not find their way into the Polish version. To make the text more familiar to the Polish reader, the translator uses the Polish version of the first name of name Lorenzo Medici: Wawrzyniec and his cognomen Magnifico is rendered as Wspaniaty. The translator does not strive to preserve the characteristics of the original, but rather to produce an intelligible and easily digestible text whose language becomes transparent, at the cost of reducing George Eliot's style to plain discourse devoid of any idiosyncrasies. In many cases, Eliot's English transliterations of Tuscan expressions are omitted, and only a few phrases in Italian find their way into the Polish text. George Eliot herself supplied a number of footnotes to the novel providing English translations of the Italian phrases used in the main text, and several such expressions are preserved in Noce florenckie, with the footnotes providing their Polish translation. For example, the Italian phrase "Chi abbaratta-baratta-b'ratta-chi abbaratta cenci e vetri-b'ratta ferri 
vecchi?"3 (Eliot 1994, 13) finds its way into the Polish version, and George Eliot's footnote translation "Who wants to exchange rags, broken glass, or old iron" is rendered in a Polish footnote: "Kto wymienia gałgany, szkła i stare stare żelastwo" (Anon. n.d., 7). [Lit. "Who exchanges rags, glass and old iron"].

However, it must be noted that the translator's approach towards foreign expressions lacks consistency. In some cases he chooses to retain them in the original Italian, but he does not include George Eliot's explanatory notes. For example, George Eliot uses the word "Palle" (Eliot 1994, 17) in the passage that refers to unusual phenomena surrounding the death of Lorenzo Medici, and in the footnote explains that Palle refers to "Arms of the Medici" (Eliot 1994, 556). In the Polish version, the word Palle is followed by an exclamation mark and left with no explanation (Anon. n.d., 9). Similarly, the translator retains the phrase "Boto caduto in Santissima Nunziata," but excises George Eliot's explanatory footnote, "A votive image of Lorenzo, in wax, hung up in the church of the Annunziata, supposed to have fallen at the time of his death. Boto is popular Tuscan for Voto" (Eliot 1994, 556-57). Arguably, readers may find the presence of footnotes more intrusive that the presence of some untranslated foreign phrases which, in the Polish version, seem to have a purely ornamental function, but are not essential for understanding the story. The footnotes interrupt the flow of reading; thus, the translator who privileges fluency and aims to produce a text which focuses on the personal plot may decide to limit their number. For George Eliot, however, the footnotes are essential because they create a richly detailed historical and cultural context which is as important as the personal plot.

Overall, in the Polish translation of Romola, the vocabulary and syntax are simplified; many Latin and Italian expressions and quotations of poetry are removed. Reflective and philosophical passages are excluded, long conversations between characters are reduced to short exchanges. For example, George Eliot characterizes Bartolomeo Scala, secretary of the Florentine Republic in the following way:

Scala was a meritorious public servant, and, moreover, a lucky man — naturally exasperating to an offended scholar; but then, — O beautiful balance of things! - he had an itch for authorship, and was a bad writer - one of those excellent people who, sitting in gouty slippers, "penned poetical trifles" entirely for their own amusement, without any view to an audience, and consequently, sent them to their friends in letters, which were the literary periodicals of the fifteenth century. Now Scala had abundance of friends who were ready to praise his writings: friends like Ficino and Landino - amiable browsers in the Medicean park along with himself — who found his Latin prose style elegant and masculine; and the terrible Joseph Scaliger, who was to pronounce him totally ignorant of Latinity, was at a comfortable distance in the next century. (Eliot 1994, 74).

In the Polish version, the rich descriptive passage, with its complex syntax, gently ironic tone, and references to actual cultural practices and real-life characters, such as Joseph Justus Scaliger (1540-1609), known both for his learning and for his sharp criticism of his fellow men of letters, is reduced to one short sentence: "Scala był

${ }^{3}$ Italics in the original. 
zasłużonym działaczem, a ponadto człowiekiem, który wyciągnął wielki los; ale oprócz tego - o piękna równowaga rzeczy—miał żyłkę literacką i był lichym pisarzem” (Anon. n.d. 48). [Lit. "Scala was a meritorious servant, and moreover a fortunate man; but on top of that - beautiful balance of things! - he had a flair for writing and was a poor writer."']. In further attempts to simplify the text for the Polish reader, the translator shuns the challenge of rendering the differences between various characters' unique use of language which reflects their position in Florentine society. These differences get largely ignored, and all the characters speak more or less standard Polish.

One of the characteristic features of George Eliot's prose style is its grammatical complexity. Her syntax is intricately constructed, and sometimes purposefully convoluted. A fellow Victorian novelist, Anthony Trollope, wrote that "she lacks ease" (Trollope 1982, 150); indeed, her novels are not easy to read, but they are not intended to be easy. Her sentences are long and demand attention from the reader. However, the Polish translation in no way reflects her literary style. For example, the first sentence of Chapter Two of Romola reads: "After Bratti had joined the knot of talkers, the young stranger, hopeless of learning what was the cause of the general agitation, and not much caring to know what was probably of little interest to any but born Florentines, soon became tired of waiting for Bratti's escort; and chose to stroll round the piazza, looking out for some vendor of eatables who might happen to have less than average curiosity about public news" (Eliot 1994, 24). In the Polish version, the sentence is divided into two and significantly abridged. It is rendered as "Młodemu cudzoziemcowi wkrótce sprzykrzyło się czekać na Brattiego. Począł więc przechadzać się po placu, wypytując jakiegoś mniej ciekawego nowin sprzedawcy żywności” (Anon.n.d., 12) [Lit. "The young stranger soon got tired of waiting for Bratti. He started to walk around the square looking for a food seller less interested in the news."'] To further domesticate the text, the translator replaces the Italian word piazza with the Polish word plac [square] and interprets the title of Chapter Two, "A Breakfast for Love" using a familiar Polish idiom "Śniadanie za piękne oczy” (Anon. n.d., 12).

As stated above, Noce florenckie was published as an installment in the Film Library intended for a popular readership. However, it is difficult to determine how many copies of the books were sold in the nineteen-twenties. The publishers did not share their circulation figures, and the retrospective Bibliography of the National Library of Poland does not contain complete information concerning individual print runs. On the basis of the available data, it can be estimated that a typical edition of a novel translated from the English language varied between two thousand and two thousand five-hundred copies, while the editions of popular novels by Polish authors reached as many as fifteen thousand copies. Arguably, it was more profitable for the publishers to publish translation of several different works in small numbers than to risk a large edition of one book that might not sell enough copies to recoup the initial outlay (Kurowska 1987, 43). The publication of the Polish translation of Romola did not lead to an increased awareness of George Eliot's oeuvre among Polish readers. Noce florenckie was never reprinted, never reviewed in any literary journal, and can be found in very few Polish libraries. The National Library of Poland has only the second volume of the Polish edition among its holdings, and both volumes are listed in the catalogue of the Jagiellonian University 
Library; however, few people are aware of their existence. ${ }^{4}$ George Eliot's novel still awaits a translator who will move Polish readers towards the complex and multifaceted textual universe of Romola.

\section{REFERENCES}

Anonymous. 1927. "Kino Renaissance.” Rewia, March 20, 1927. 19.

Anonymous, trans. N.d. Romola: Noce florenckie by George Eliot. Warszawa: Edward Wende.

Booth, Bradford Allen, ed. 1951. The Letters of Anthony Trollope. London: Oxford University Press.

Brown, Andrew. 1994. "Introduction" to Romola, by George Eliot, vii - xxiv. Oxford: Oxford University Press.

Dobosiewicz, Ilona. 2016."The Reception of George Eliot in Poland". In The Reception of George Eliot in Europe, edited by Elinor Shaffer, and Catherine Brown, 318-335. London: Bloomsbury Academic.

Eliot, George. 1994. Romola. Oxford: Oxford University Press.

Haight, Gordon S. 1978. George Eliot: A Biography. Oxford: Oxford University Press.

Harris, Margaret, and Judith Johnston, eds. 2000. The Journals of George Eliot. Cambridge: Cambridge University Press.

James, Henry. 1971. "Henry James on George Eliot." In George Eliot: The Critical Heritage, edited by David Carroll, 490-504. London: Routledge\&Kegan Paul.

Kurowska, Elżbieta. 1987. Recepcja literatury angielskiej w Polsce (1932-39). Wrocław: Ossolineum.

Lee, Tong King. 2018. Applied Translation Studies. London: Palgrave.

Lefevere, André, ed. and trans. 1977. Translating Literature: The German Tradition from Luther to Rosenzweig. Assen: Van Gorcum.

Scholl, Lisa. 2016. Translation, Authorship and the Victorian Professional Woman. London: Routledge.

Szala, Alina. 1982. "Wstęp" to Mtyn nad Flossa, edited by George Eliot, iii-cvi. Trans. Anna Przedpełska-Trzeciakowska. Wrocław: Zakład Narodowy imienia Ossolińskich.

Trollope, Anthony. 1982. "On George Eliot." In A Century of George Eliot Criticism, edited by Gordon S. Haight, 150-151. New Haven: Yale University Press.

Trott, Nicola. 2003. "The Difficulty of Italy: Translation and Transmission in George Eliot's Romola." In Unfolding the South: Nineteenth-Century British Women Writers and Artists in Italy, edited by Alison Chapman, and Jane Stabler, 137-158. Manchester: Manchester University Press.

Venuti, Lawrence. 1995. The Translator's Invisibility: A history of translation. London: Routledge.

\footnotetext{
4 Alina Szala, who penned a scholarly introduction to the 1982 edition of George Eliot's Mill on the Floss published in the canon-making series Biblioteka Narodowa by Ossolineum discusses Polish translations of George Eliot's works, but makes no reference to Noce Florenckie.
} 
This work is licensed under the Creative Commons Attribution 3.0 Unported License. http://creativecommons.org/licenses/by/3.0/

AUTHOR'S BIO: Ilona Dobosiewicz, Professor at the University of Opole, Poland, received her Ph.D. from Illinois State University, USA and her D.Litt. degree from University of Opole, where she teaches English literature. She is the author of books: Female Relationships in Jane Austen's Novels (1997), Ambivalent Feminism: Marriage and Women's Social Roles in George Eliot's Works (2003), and Borderland: Jewishness and Gender in the Works of Amy Levy (2016) as well as articles on the nineteenth-century British and American literature and culture which appeared in academic journals and edited collections published by Palgrave-Macmillan, Bloomsbury Academic, Cambridge Scholars, Peter Lang, and university presses in Poland, France, and Portugal.

E-MAIL: ildob@uni.opole.pl 